PAEDAGOGIA CHRISTIANA

$1 / 25$ (2010) - ISSN 1505-6872

\author{
Jarostaw Gara* \\ Warszawa
}

\title{
Filozofia dialogu i jej implikacje pedagogiczne
}

Pycha posiadania absolutnej prawdy niszczy prawdę $\mathrm{w}$ świecie. $\mathrm{W}$ pewności niezbędna jest pokora trwania w pytaniu. Albowiem wszystko może się jeszcze okazać czymś zupełnie innym ${ }^{1}$.

Sposób pojmowania podmiotowości ludzkiej uznać należy za centralne zagadnienie filozofii dialogu. Dialogika postrzega bowiem człowieka jako tego, który jest bytem samym w sobie, ale jednocześnie też jako tego, który jest bytem skierowanym ku innym. Ów „podwójny ruch” jest więc czymś specyficznym dla dialogicznej charakterystyki ludzkiej podmiotowości i wyraża się w zdolności przejścia od bycia dla siebie do bycia dla innych; od bycia samotnym „brzegiem” do bycia przeciwległym „brzegiem”, na który przerzucony zostaje most, od egoizmu odłączenia do odpowiedzialności „za” i „wobec”. W myśli Franza Rosenzweiga (1886-1929) uwidocznione zostaje to w przejściu od Sobości do miłującej duszy², u Martina Bubera (1878-1965) od Samoistoty (Eigenwesen) do osoby ${ }^{3}$, a u Emanuela Levinasa (1906-1995) od ateizmu bycia (separacji) Toż-Samego do metafizycznego pragnienia bycia dobrym „dla”"

* Dr Jarosław Gara, adiunkt na Wydziale Nauk Pedagogicznych Akademii Pedagogiki Specjalnej w Warszawie oraz na Wydziale Stosowanych Nauk Społecznych i Resocjalizacji Uniwersytetu Warszawskiego.

${ }^{1}$ K. Jaspers, Człowiek, w: Filozofia egzystencji, Warszawa 1990, s. 44.

2 F. Rosenzweig, Gwiazda Zbawienia, Kraków 1998, s. 162-163.

${ }^{3}$ Zob. K. Święcicka, Relacja dialogiczna w ujęciu Martina Bubera, w: tenże, Transcendentalizm Husserla a filozofia dialogu, Wrocław 1993, s. 78.

${ }^{4}$ E. Levinas, Całość i Nieskończoność. Esej o zewnętrzności, Warszawa 2002, s. 262, 305. 
Do przedstawicieli filozofii dialogu zaliczyć można przede wszystkim: Hermana Cohena (1842-1918), Ferdinanda Ebnera (1882-1931), Eugena Rosenstocka-Hussey (1888-1973), Gabriela Marcela (1889-1973), Dietricha Bonhoeffera (1906-1945), Eberharda Grisebacha (1880-1945), Karla Bartha (1886-1968), Abrahama Joshuę Heschela (1907-1972), Józefa Tischnera (1931-2000), jak również Jean-Luc Mariona (ur.1945)5. Co więcej, problem międzypodmiotowej relacji oraz dialogicznego sposobu konstytuowania się podmiotowości ludzkiej podejmowany był przez owych dialogików na różne sposoby. I tak Cohen oraz Grisebach zagadnienie relacji międzypodmiotowej rozpatrywali przez pryzmat kategorii etycznych; Ebner i Rosenstock-Hussey koncentrowali się na „dialektycznym” wspólistnieniu Ja i Ty; Marcel i Marion eksponowali międzypodmiotowy fenomen miłości; Bonhoeffer i Barth koncentrowali się na problemie wspólnoty i współbycia, natomiast u Heschela i Tischnera możemy odnaleźć motyw niejednoznaczności i problematyczności ludzkiej egzystencji.

\section{Przegląd wybranych stanowisk filozofii dialogu}

Dla Cohena osobowe Ty implikuje problematykę etyczną, ponieważ należy je odróżnić od bezosobowych form On i To. Autor ten podkreśla zarazem, że odkrycie Ty prowadzi do uświadomienia sobie samego siebie (własnego Ja). Odwołując się do pojęcia korelacji, wskazuje również, że człony korelacji nie są oparte na podobieństwie, lecz na różnicy i dlatego są nieporównywalne ${ }^{6}$. Z kolei Grisebach dokonuje rozróżnienia na Ja i Ty oraz stwierdza, że Ja jest uosobieniem egoizmu istnienia, ponieważ chodzi $\mathrm{mu}$ jedynie o afirmację siebie i marginalizację innych ${ }^{7}$. Zwalczając innych, Ja dąży bowiem do umacniania swych hegemonicznych roszczeń, dlatego też ludzka ,jaźń jest największym niebezpieczeństwem etycznej rzeczywistości"». Tyranii Ja przeciwstawić należy zatem Ty, ponieważ tylko władza innego człowieka może położyć kres roszczeniowości Ja.

Według Ebnera, filozofia prawdziwa musi wyrzec się wszelkiej obiektywizacji, ponieważ każda jej postać spycha Ty na margines ważności. Filozofia trzeciej osoby w gruncie rzeczy jest filozofią pierwszej osoby, a Ja

${ }^{5}$ Por. T. Gadacz, Historia filozofii XX wieku. Nurty, t. 2, Kraków 2009, s. 503-613; B. Milerski, Pedagogika dialogu: filozoficzne inspiracje i perspektywy, w: E. Dąbrowa, D. Jankowska (red.), Pedagogika dialogu. Dialog warunkiem rozwoju osobowego i społecznego, Warszawa 2008, s. 29-33.

${ }^{6}$ B. Baran, Przedmowa, w: tenże (red.), Filozofia dialogu, Kraków 1991, s. 11.

${ }^{7}$ E. Grisebach, Doświadczenie i spotkanie, w: B. Baran (red.), Filozofia, s. 111.

8 Tamże, s. 111. 
może istnieć tylko w relacji do Ty ${ }^{9}$. Rosenstock-Hussey zakładał z kolei, że dusza ludzka posiada własną gramatykę w postaci „systemu słownego”, a więc ten, kto chce poznać tajemnicę duszy, nie może się obejść bez zgłębienia tajemnicy mowy ${ }^{10}$. Gramatyka duszy posiada swą własną kolejność osób, na pierwszym miejscu jest tu bowiem druga osoba (Ty). W ten sposób ustanowiony zostaje zupełnie odmienny porządek, niż ten ukonstytuowany gramatyką języka. Dlatego też Ja odkrywa siebie tylko wtedy, gdy Ty zwraca się, mówi do niego.

Kolejny filozof, Marcel, w swych rozważaniach podkreślał, że racją podstawową odniesienia względem osoby jest miłość, poznanie zaś racją odniesienia do rzeczy. Co więcej relacja Ja-Ty jest dla niego zawsze określana stosunkiem sytuacji pytania i odpowiedzi. „To” zyskuje status Ty, gdy skierowane zostanie do niego pytanie, czyli gdy potraktowane zostanie dialogicznie. Według Marcela, tą ,ty to nie jest tylko ktoś zapytywany jako taki ty, jest zapytywany, o ile samo ty nie jest traktowane jako przedmiot pytań"11. Takie przeformowanie sposobu odniesień wobec innych jest zatem przejściem od dialektyki do dialogiki. Marion odwołując się do pojęcia miłości podkreślał natomiast, że jest ona (miłość) tym, co odzwierciedla w sposób najbardziej pełny dialogiczność istnienia, będąc tym samym najwyższą formą dialogicznej relacji ${ }^{12}$. Relacja z innym człowiekiem jest więc spotkaniem się spojrzeń dwóch intencjonalności, w miłości dochodzi bowiem do spotkania się dwóch podmiotów. Dlatego też spotkanie z Innym jako podmiotem nie pozwala już zajmować centralnej pozycji przez podmiot intencjonalności pośród obiektów, będących li tylko przedmiotem intencjonalnych aktów.

Punktem wyjścia rozważań Bonhoeffera jest z kolei wspólnota, jako że człowiek jest od razu w niej stworzony ${ }^{13}$. Człowiek w swej jednostkowości ujmowany jest zatem przez niego jako ten, który jest jednostką dlatego, że jest ktoś inny. Ja i Ty są jednak członami relacji, niesprowadzalnymi do siebie nawzajem, reprezentując tym samym odmienne treści doświadczenia. Stosunek do innego człowieka wykracza jednak też poza relację ujmowaną w kategoriach podmiotowo-przedmiotowych, ponieważ z drugim człowiekiem łączy mnie relacja etyczna ${ }^{14}$. Z kolei Barth zakładał, że wydarzenie spotkania drugiego człowieka jest czymś, co stanowi o jego człowieczeństwie. Powinnością etyczną ludzi jest zatem pielęgnowanie autentyzmu

\footnotetext{
${ }^{9}$ F. Ebner, Fragmenty pneumatologiczne, w: B. Baran (red.), Filozofia, s. 87, 83.

${ }^{10}$ E. Rosenstock-Huessy, Gramatyka duszy, w: B. Baran (red.), Filozofia, s. 98.

${ }^{11}$ G. Marcel, Dziennik metafizyczny, Warszawa 1987, s. 175.

${ }^{12}$ J.-L. Marion, Intencjonalność miłości, w: B. Baran (red.), Filozofia, s. 255.

${ }^{13}$ D. Bonhoeffer, Wybór pism, Warszawa 1970, s. 11.

${ }^{14}$ Tenże, Naśladowanie, Poznań 1997, s. 40.
} 
i przeciwdziałanie nieautentyczności spotkania ${ }^{15}$. Człowieczeństwo „każdego człowieka - zauważa myśliciel - polega na tym, że istotą określającą jego bycie jest współbycie z innym człowiekiem"16.

Heschel wreszcie wskazywał, że cechą charakterystyczną człowieka jest to, że chce on wiedzieć, kim jest i w relacji do kogo się znajduje. Nie wystarczy mu więc pewność, że istnieje, poszukuje on bowiem rozwikłania problemu statusu swej tożsamości. Zrozumienie swego bycia jest też nieodzownym warunkiem uskuteczniania swego człowieczeństwa ${ }^{17}$. Człowieka traktować należy zatem jako problem („,czym i w relacji do czego jestem”), a nie jako pytanie („czy jestem”). Dlatego też problem jest wynikiem sytuacji, zaś pytanie aktem intelektu ${ }^{18}$. Natomiast Tischner w sposób szczególny podkreślał, że człowiek jako podmiot spotkania uczestniczy w dramacie rzeczywistości, tak iż „perspektywa tragiczności jest nieodłącznym tłem każdego spotkania" ${ }^{19}$. „Spotkanie z innym - pisze Tischner - to spotkanie z tym, co naprawdę jest poza mna. Drugi to po prostu transcendens. Drugi stawia mnie w sytuacji, w której nawet pominięcie go jest formą przyznania, iż jest”20.

\section{Najbardziej wpływowi przedstawiciele filozofii dialogu}

Za najbardziej wpływowych i rozpoznawalnych przedstawicieli myśli dialogicznej uznać należy jednak Franza Rosenzweiga, Martina Bubera i Emmanuela Levinasa, dlatego ustaleniom tych filozofów przyjrzymy się nieco bliżej ${ }^{21}$.

Człowiek, jak to wskazuje Rosenzweig, nie jest prostym ujednostkowieniem rodzaju ludzkiego, ale raczej nieredukowalną jednostkowością poza wszelkim pochłaniającym ethosem jakiejkolwiek ogólności, poza wszelką zneutralizowaną formą bycia trzeciej osoby ${ }^{22}$, ludzka jednostkowość posiada $-161$.

${ }^{15}$ K. Barth, Podstawowa forma człowieczeństwa, w: B. Baran (red.), Filozofia, s. 143-

16 Tamże, s. 133.

17 W. Szczerbiński, Abrahama Jeshuy Heschela filozofia człowieka, Lublin 2000, s. 139.

${ }_{18}$ T. Gadacz, Historia filozofii XX wieku. Nurty, t. 2, s. 616-617.

19 J. Tischner, Filozofia dramatu, Kraków 2001, s. 64.

${ }^{20}$ Tamże, s. 66.

${ }^{21}$ Zob. także: J. Gara, Pedagogiczne konteksty tez filozofii dialogu, „Człowiek - Niepełnosprawność - Społeczeństwo" 1/3 (2006); tenże, Pedagogiczny model dialogicznych aktów wychowania, „Kwartalnik Pedagogiczny” 1 (2007); tenże, Filozoficzne przestanki intersubiektywności dialogiki aktów wychowania, „Horyzonty Wychowania” 7 (2007), nr 12; tenże, Pedagogiczne implikacje filozofii dialogu, Kraków 2008.

${ }^{22}$ A. Żak, Punkt wyjścia filozofii Franza Rosenzweiga, w: Zawierzyć czlowiekowi. Księdzu Józefowi Tischnerowi na sześćdziesique urodziny, Kraków 1991, s. 473. 
więc własną logikę i autonomię ${ }^{23}$. Rosenzweig, ujmując człowieka w jego niezastępowalności i nieredukowalności, dezintegruje systemową możliwość uprzedmiotowienia w ,bezosobowym szeregu”; w ten sposób przywraca mu autentyczną realność i faktyczność. Czyni to poprzez odwołanie się do faktu nieuniknioności przeżycia własnej śmierci, która to implikuje nieuniknioność podjęcia odpowiedzialności za własne życie.

Według tego filozofa człowiek jest sam dla siebie „własnym światem”, jest zatem jak brzeg rzeki, nad którą musi zostać rozpostarty most, by spotkać innego człowieka - ,inny świat”, czyli przeciwległy brzeg rzeki. Sobość jest życiem ,poza granicami gatunku”24 i dlatego jest najbardziej własną podmiotowością"25, od której może wyjść chęć zwrócenia się ku temu, co zewnętrzne, ponieważ człowiek ,w bezwarunkowej jednostkowości swej własnej istoty"26 to ktoś, kto posiada imię i nazwisko; ktoś, kogo byt określony jest własną jednostkową identyfikacją kogoś konkretnego - niepodmienialnego i niezastępowalnego. Ujęcie człowieka jako osobowe Ty znosi zatem prawomocność gramatyki trzeciej osoby z jej tonem neutralności (on, ona, ono $)^{27}$, ponieważ ton ten prowadzi do zaniku jakiejkolwiek odrębności - tam, gdzie nie ma konkretnego podmiotu z imieniem i nazwiskiem, podmiotem tym może być każdy, czyli nikt konkretny. Ludzkie Ja jest więc faktycznym podmiotem, gdy może wypowiadać siebie z imienia i nazwiska, a nie ,przed i poza wszelką biografią", ahistorycznie. Bezpośrednia określoność własnego imienia nadaje więc jednostce jej własne, niepowtarzalne znaczenie, ponieważ nie jest już nieidentyfikowalnym budulcem gatunku. Posiadając imię własne, człowiek nie może być czyjąkolwiek rzeczą, ponieważ jest własnym gatunkiem ${ }^{28}$. Ludzka Sobość jest wolna i dlatego wezwana jest do wyboru, sam wybór zaś jest tu czymś rzeczywistym, egzystencjalnie brzemiennym w skutki i rozstrzygającym ${ }^{29}$. Człowiek wybrany daje odpowiedź swoim wyborem, a rozbudzona dusza dokonuje wyboru zwrócenia się do świata, potwierdzając tym samym swą dojrzałość. Poprzez wybór wkraczamy więc w rzeczywistość, która kreowana jest właśnie owym wyborem i bez niego by nie zaistniała.

Co więcej, dla Rosenzweiga dialogiczna relacja wytyczana jest słowem „i”: Bóg i człowiek, Bóg i świat, człowiek i świat. W tym stosunku wytycza-

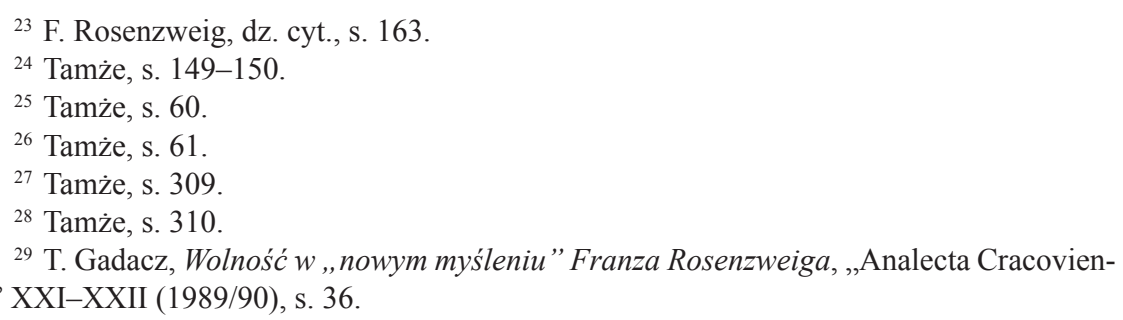


nym łącznikiem ,i” rodzi się doświadczenie prawdy, która jest dialogiczna, tak jak relacja wytyczająca jej zaistnienie ma taki charakter i konstytuuje się dzięki słowu. Skierowane pytanie i dana odpowiedź jest tym, co tworzy relację wspólnoty, a wyższy poziom ludzkiego istnienia to właśnie ten, gdzie istnieje relacja, w której ktoś się zwraca, prosi, oczekuje ${ }^{30}$ - to „zanurzenie” w mowie, która jest komunikacją, pytaniem i odpowiedzią ${ }^{31}$ Mowa $\mathrm{z}$ kolei, która jest wzajemnym odniesieniem, to medium wyłaniania się dialogiczności $^{32}$. Słowo rodzi relację dialogu i dzięki niemu człowiek staje naprzeciw człowieka, przełamane zostaje wyobcowanie - rodzi się dialog ${ }^{33}$. Prawda odsłaniana przed człowiekiem wyłania się w relacji, która jest negacją monologiczności. Prawda jest wielowymiarowa, nigdy w pełni nie jest dostępna odseparowanej, zamkniętej we własnym świecie jednostce, ponieważ dopiero w relacji wspólnych odniesień i dialogu zyskuje ona pełnię i całośćc ${ }^{4}$.

Buber w swych rozważaniach wskazuje na to, że relacja z drugim człowiekiem jest czymś nieodzownym na drodze konstytucji własnego osobowego istnienia. Zwrócenie się ku drugiemu człowiekowi możliwe jest jednak tylko dzięki posiadaniu własnego punktu wyjścia (bycia u siebie), to zaś zwraca naszą uwagę na dwoistość zasady ludzkiego bytu, która wyraża się w podwójnym ruchu - dystansowaniu się i wejściu w relację ${ }^{35}$. To, że pierwszy ruch (dystansowanie się) jest warunkiem drugiego (wejście w relacje), oparte jest zaś na założeniu, że w relację można wejść tylko z bytem, do którego się uprzednio zdystansowało, czyli takim, który jest samostanowiącym się „Naprzeciw”36.

Dla Bubera człowiek jest jak „mikrokosmos”, czyli ktoś, kto posiada swą samodzielną i w pełni autonomiczną strukturę bytu. Jest to zatem ktoś inny, kto nie może być tożsamy ze mną, ponieważ jest inną istotą i jako kogoś innego właśnie potrzebuję go, by w pełni odkryć samego siebie, urzeczywistniając tym samym swój osobowy byt. Drugi człowiek pojmowany jako ktoś inny niż my sami nadaje sens przestrzeni dialogicznej, ponieważ tylko wtedy może on stanąć naprzeciw nas samych. I właśnie ta niereduko-

${ }^{30}$ Tenże, Prawda w ,nowym myśleniu” Franza Rosenzweiga, w: B. Baran, T. Gadacz, J. Tischner (red.), Rozum i stowo. Eseje dialogiczne, Kraków 1987, s. 92.

${ }^{31}$ A. Żak, ,Myślenie mowy” jako nowy racjonalizm w ujęciu Franza Rosenzweiga, w: B. Baran, T. Gadacz, J. Tischner (red.), dz. cyt., s. 74.

${ }^{32}$ Tamże, s. 80.

33 T. Gadacz, Prawda, s. 91.

${ }^{34}$ Tamże, s. 94-95.

${ }^{35}$ M. Buber, Pradystans i relacja, w: tenże, Ja i TY. Wybór pism filozoficznych, Warszawa 1992, s. 127.

${ }^{36}$ Tenże, Dialog, w: tenże, Ja i Ty, s. 231. 
walna inność drugiego człowieka ${ }^{37}$ zmusza do przekraczania granicy swej własnej egzystencji, by mogło wydarzyć się spotkanie - by mogła zaistnieć relacja Ja i Ty.

Miarę człowieka poznaje się - jak twierdził Buber - po możności wejścia w dialogiczny związek ${ }^{38}$. Dlatego też najbardziej doniosłym faktem ludzkiego życia - w myśl tak zwanej zasady dialogicznej (das dialogische Prinzip) - jest nie tyle indywidualistyczna możliwość monadycznego odłączenia, co raczej rzeczywistość „człowieka z człowiekiem”39, czyli relacja, w której każdy wykracza poza obręb tego, co własne. Taka perspektywa filozoficznego ujmowania człowieka jako „dynamicznej dwójni” wytycza bezpośredniość stosunku międzyludzkiego, w którym uwidacznia się to, co tylko człowiekowi jest właściwe, ponieważ istota człowieka uchwytna jest jedynie w optyce owej „dwójni”. W ten sposób dzięki wejściu w relację człowiek objawia się jako człowiek ${ }^{40}$, jednak to, czy wejdzie w tę relację, jest jego wolnym wyborem. Dlatego prawdziwą wolność odkrywa właśnie osoba ze względu na to, że tylko ten, kto wie o obecności swojego „Naprzeciw”, może podjąć faktyczną decyzję ${ }^{41}$. Człowiek ma zatem moc dystansować się (postawa monologiczna) lub wejść w relację (postawa dialogiczna), dokonując tym samym wyboru sposobu postrzegania otaczającej rzeczywistości oraz sposobu komunikowania się z nią. Relacja ta opiera się więc na byciu bytem wybranym i wybierającym. Człowiek zagadywany zawsze daje jakąś odpowiedź ${ }^{42}$, ale nie zawsze wybiera dialogiczną postawę, dlatego też owa wolność wyboru wyłania faktyczną przestrzeń dramatu ludzkiej egzystencji. Oznacza to zbliżenie lub oddalenie, ofiarowanie siebie Drugiemu w „czynie miłości" lub też zagarnięcie i podporządkowanie go sobie w akcie uprzedmiotawiającej redukcji, współtworzenie więzi lub negację potrzeby istnienia wspólnotowości.

„Fundamentalnym faktem ludzkiej egzystencji - pisze Buber - jest człowiek z człowiekiem. Świat ludzi znamionuje przede wszystkim to, że tutaj wydarza się między istotą a istotą coś, czego nie znajdzie się nigdzie w przyrodzie" ${ }^{\prime 3}$. Człowiek napotyka na swej drodze rzeczy i ludzi, przy czym odkrywanie zarówno rzeczy, jak i ludzi przebiega w inny sposób. Rzeczy odnajdywane są jako obiekty, ludzie zaś powinni być ujmowani jako oso-

${ }^{37}$ Tenże, Problem człowieka, Warszawa 1993, s. 89.

38 Tamże, s. 93.

${ }^{39}$ Tamże, s. 90-91. Zob. także: tenże, Między osobq a osobq, w: tenże, Ja i Ty, s. 150.

${ }^{40}$ Zob. A. Żak, Marcin Buber o możliwości objawienia, „Analecta Cracoviensia” XXIII (1991), s. 120.

${ }^{41}$ M. Buber, Ja i Ty, w: Ja i Ty, s. 70.

${ }^{42}$ Tamże, s. 26.

${ }^{43}$ Tenże, Problem czlowieka, s. 91. 
by. Stąd też rzeczy doświadczamy, a obecność ludzi przeżywamy ${ }^{44}$. W doświadczaniu rzeczy jesteśmy intencjonalnie ku niej zwróceni, przeżywanie obecności człowieka nie może zaś być zamierzone i nie da się zaplanować. Poznanie rzeczy dane jest w jej doświadczeniu i jest wybiórcze; poznanie człowieka dane jest $\mathrm{z}$ kolei w relacji i jest ogarnięciem całej osoby ${ }^{45}$.

"Człowiek z człowiekiem” to sfera międzyludzka, naturą której jest dialog oparty na rozmowie, wzajemnym odniesieniu się do siebie. Tym samym Buber dokonuje zasadniczego rozróżnienia, które odwołuje się do dwóch par słów, ,prasłów”: Ja-Ty oraz Ja-To. Owe ,prasłowa” reprezentują dwa „sposoby bycia" - pierwszy z nich wytyczany jest relacją, drugi zaś posiadaniem. Dialog, tworząc stosunek wzajemności, zakłada natomiast dwubiegunowość relacji i „podwójność ról: mówienie i słuchanie, przekazywanie i odbieranie, dawanie i branie" ${ }^{46}$. Dialog wyłania jakości, które nie mogą się zrodzić nigdzie indziej, jak tylko w przestrzeni ,pomiędzy”. Ja istnieje bowiem w nierozerwalnym związku z Ty, a zawsze, gdy wypowiadamy Ja, samoistnie wypowiedziane zostaje również Ty i na odwrót. „Kreatywna funkcja dialogu” polega więc na tym, że jednocześnie konstytuuje się w nim Ja i Ty. Ty jest warunkiem istnienia Ja, a Ja jest nieodzowne istnieniu Ty ${ }^{47}$.

W końcu Levinas zakładał, że drugi człowiek jest całkowicie i radykalnie inny. Oznacza to, że Drugi nie może być redukowany do sfery mej własnej tożsamości. Immanencja mego własnego ,ja” nie może być dlatego horyzontem zawężającym jego istnienie ${ }^{48}$. Inny, który jest zupełnie różny ode mnie, pozostaje poza wszelką kategoryzacją rozumu ${ }^{49}$, jest transcendencją. A zatem przekracza on me własne wyobrażenia i zdolności rozumowania, jak również adekwatność mych odczuć i intuicji. By doświadczyć radykalnej inności drugiego człowieka, trzeba zatem posiadać swe własne wnętrze. Doświadczenie inności Innego rodzi też faktyczne doświadczenie siebie, ze względu na to, że dzięki doświadczeniu odmienności Innego wiem, że ja sam jestem sobą ${ }^{50}$. Dlatego też uznaniu czyjejś inności towarzyszy świadomość własnej tożsamości, a odrębność nie jest negacją możliwości spotkania Drugiego. Ono bowiem wyrasta paradoksalnie z separacji i zachowania swej inności, poprzez pragnienie zarówno siebie, jak i pragnienie Innego, s. 876 .

${ }^{44}$ H. Buczyńska-Garewicz, Martin Buber i dylematy subiektywności, „Znak” 7 (1980),

${ }^{45}$ Tamże, s. 876.

${ }^{46}$ Tamże, s. 882.

${ }^{47}$ Tamże, s. 882, 887.

${ }^{48}$ B. Baran, Przedmowa, s. 29.

49 J. Tischner, Emmanuel Levinas, w: tenże, Myślenie wedtug wartości, Kraków 1993, s. 188

${ }^{50}$ B. Baran, Przedmowa, s. 30-31. 
a nie z totalizującego dążenia do „tego samego"51. Kontakt z Innym, jedność z nim, jest zatem ,jednością w różnicy”, jednością z tym, który nie przestaje być Innym $^{52}$. Nie mogę się z nim scalić lub wchłonąć go, lecz jedynie zastąpić lub oddać się mu w relacji, która jest oparta na różnicy.

W związku z tym relacja intersubiektywana możliwa jest właśnie dzięki separacji, która jako swoisty egoizm bycia stanowi niejako „macierz” formowania się podmiotowości danego człowieka. Rzeczywista separacja daje bowiem możliwość wyłonienia się relacji, której pozytywność polega na tym, że inny człowiek nie może być antycypowany przez Toż-Samego (le Même $)^{53}$. Zatem do Innego (l'Autre) zwracać można się jedynie ,po omacku, jak do czegoś absolutnie innego, nieprzewidywalnego" ${ }^{54}$. Co więcej, byt odseparowany jako byt ateistyczny jest zupełnie sam w swym istnieniu i nie partycypuje w tym, od czego jest oddzielony. „Byt odseparowany - pisze Levinas - jest zaspokojony, niezależny, a jednak szuka Innego, choć tego poszukiwania nie pobudza ani potrzeba, ani wspomnienie utraconego dobra" Levinasowski model podmiotowości nie opiera się zatem na neurotycznej potrzebie posiadania kogoś, lecz ujęty jest jako gościnność, która przyjmuje drugiego człowieka ${ }^{56}$, nadchodzącego spoza sfery tego, co się nabywa i posiada, a więc włącza w krag swego bycia. Prawdziwa podmiotowość jest nieujmowalna, bo jest swego „własnego rodzaju”, stąd też prawdziwe „razem”, czyli relacja, nie jest „razem syntezy”, lecz razem „twarzą w twarz”"57. Levinas odrzuca więc taki typ odniesienia, na mocy którego punktem wyjścia jest totalizujące roszczenie Toż-Samego wobec Innego, podkreślając rangę epifanii twarzy Innego jako wydarzenia wyłaniającego prawdziwą intersubiektywność - relację metafizyczną, w której nie zostają poddane zatarciu ani inność Innego, ani identyczność Toż-Samego ${ }^{58}$.

Levinas w swej apologii subiektywności podmiotu i źródłowego szacunku dla podmiotowości ludzkiej ujmuje zarazem człowieka w antropologicznej formule: ,jeszcze nie”. Byt, który jest ,,jeszcze nie”, oznacza więc: jeszcze nie umarłem, jeszcze mam czas; czas, by być dobrym i wspaniałomyślnym dla drugiego człowieka ${ }^{59}$. Opuszczać mury egoizmu bycia oznacza zaś wznosić się na pułap człowieczej wielkości, która wyrasta z reorientacji

\footnotetext{
${ }^{51}$ B. Skarga, Filozofia różnicy, „Przegląd filozoficzny” 1 (1982), s. 59.

${ }^{52}$ Tamże, s. 60.

${ }^{53}$ E. Levinas, Całość i Nieskończoność, s. 48.

${ }^{54}$ Tamże, s. 19.

55 Tamże, s. 57.

${ }^{56}$ Tamże, s. 11.

${ }^{57}$ Tenże, Etyka i Nieskończony. Teksty Filozoficzne, Kraków 1991, s. 46-47.

${ }^{58}$ Tenże, Catość i Nieskończoność, s. 30, 60.

${ }^{59}$ Tamże, s. 248-249, 300.
} 
egzystencjalnej optyki bycia zaaferowanym doraźnością działań skoncentrowanych na własnym li tylko „kopcu”. Dlatego też w owym wykroczeniu „ku” i w byciu „dla” byt staje się dopiero człowieczy ${ }^{60}$. Ludzkie Ja w swej nieredukowalnej podmiotowości jest wybrane i wezwane zarazem ${ }^{61}$, by znaleźć własne miejsce poza powszechnością bezosobowego bycia ${ }^{62}$ dzięki swej wewnętrznej i subiektywnej moralności, która wykracza poza obiektywność w owym „więcej” pragnienia metafizycznego. W odpowiedzi na wezwanie podmiot ofiarowuje w mowie drugiemu człowiekowi posiadany przez siebie świat $^{63}$. Mowa jest tu więc sposobem, w jaki świat zostaje zaproponowany komuś innemu ${ }^{64}$, a tym samym wytycza przestrzeń relacji z Innym. Mowa przynosi też bezpośrednie doświadczenie innego bytu ${ }^{65}$, ponieważ ten, kto do nas mówi, zarazem objawia się, natomiast ten, do kogo się zwracamy, wezwany jest jednocześnie do odpowiedzi - mówienia, które jest „przychodzeniem w sukurs" ${ }^{\prime 66}$ własnym słowom. Istotą mowy jako zewnętrzności względem wewnętrzności monologu myśli jest zatem relacja $\mathrm{z}$ drugim człowiekiem, gdyż mówić to wychylać się do tego, który jest moim rozmówca. W ten sposób mowa odsyła nas do samego „rdzenia podmiotowości człowieka" ${ }^{67}$.

\section{Przesłanki eksponujące pedagogiczne implikacje filozofii dialogu}

Reasumując przewodnie intencje myśli dialogicznej, wskazać można następujące kwestie implikujące pedagogiczne pryncypia:

Drugi człowiek jest zewnętrznością, tzn. jest podobny do mnie, ale nie jest tożsamy ze mną, nie jest mną, jest inny niż ja. Innego człowieka odkryć można zatem jedynie jako kogoś zewnętrznego względem siebie samego, kogoś w kim należy uznać samoistność osobowego istnienia. Zakłada to wyczulenie na sygnały pochodzące od innych oraz pielęgnowanie głębokiego, empatycznego zrozumienia innych. Wrażliwość na sygnały płynące od

${ }^{60}$ Tenże, Filozof wobec śmierci, w: W. Chabanis, Śmierć, kres czy poczqtek?, Warszawa 1987, s. 262.

${ }^{61}$ Tenże, Simone Weil przeciw Biblii, w: tenże, Trudna wolność. Esej o judaizmie, Gdynia 1991, s. 146.

${ }^{62}$ Tenże, Całość i Nieskończoność, s. 90.

${ }^{63}$ Tamże, s. 249.

${ }^{64}$ Tamże, s. 97. Zob. także: M. Jędraszewski, Wobec Innego. Relacje międzypodmiotowe w filozofii Emmanuela Levinasa, Poznań 1990, s. 146.

${ }^{65}$ E. Levinas, Całość i Nieskończoność, s. 62, 241.

${ }^{66}$ Tamże, s. 66.

${ }^{67}$ B. Skarga, Autrement qu'être ou au-delà de l'essence, w: tenże (red.), Przewodnik po literaturze filozoficznej XX wieku, Warszawa 1994, s. 269. 
innych należałoby też uznać za jedną z podstawowych kompetencji pedagoga dialogu. Autentyczny dialog wymaga bowiem wrażliwości na innych i wyczulenia na sygnały, które stają się przesłanką do tego, by odkrywać wychowanka jako nieredukowalny do naszych profesjonalnych wyobrażeń „inny świat”.

Obecność drugiego człowieka nakłada na mnie, w mym „dumnym ja”, które zazdrośnie czuwa nad tym, co jest mu własne, powinność troski o Innego. Małość i pospolitość tkwi bowiem w działaniu mającym na względzie jedynie to, co własne. Implikuje to zatem kwestię wychodzenia „ku” i bycia „dla” innych oraz autentycznego uznania ważności drugiej osoby poprzez gotowość poświęcenia jej uwagi, bycie dostępnym, czyli otwartym na jego potrzeby. W ten sposób dialogiczne usposobienie wyraża się w podejściu, które w wychowanku zawsze widzi partnera do rozmowy, działania czy współdecydowania, z którym podąża się wspólną drogą poszukiwania prawdy i możliwych rozwiązań. Wychowawca nie chce zatem uzależniać od siebie wychowanka, lecz doprowadzić go do pełnej i dojrzałej samodzielności osobowego istnienia.

Życie, które przekracza bezruch pojęć, jest zwróceniem się człowieka w stronę świata, reprezentacją którego jest Inny, jest ,zanurzeniem w codzienności życia". Życie jako ekspresja polega na przełamywaniu form, schematów działania i stereotypów myślenia. Rodzi to postawy otwartości na świeżość inicjatyw, spontaniczność reakcji oraz bycie elastycznym w tym, co jest formą i oprawą, a nie zasadniczą treścią tego, co wydarza się w międzypodmiotowej przestrzeni styczności Ja i Ty. To również przełamywanie formalnego dystansu i tonu neutralności, ponieważ nie sprzyja to upodmiotowieniu relacji. Pozycyjność i zdystansowanie emocjonalne rodzi bowiem poczucie, że partnerem lub adresatem działań wychowawczych jest ktoś ustawiony w anonimowym i bezosobowym szeregu.

Człowiek w swej mowie zagaduje drugiego człowieka. Zagadnięcie to jest szczególną właściwością istoty ludzkiej i zasadza się na ustanowieniu i uznaniu samodzielnej inności drugiego człowieka. Prawdziwa rozmowa odzwierciedla tym samym bezpośredniość kontaktu i dlatego zawsze jest „szansą uczłowieczenia”. W autentycznej rozmowie odnajdujemy intencję otwarcia się na wychowanka, ponieważ wyraża się ona w gotowości, by podopieczny stawiał mi pytanie, wyrażał wątpliwości, formułował opinie. Faktyczna rozmowa jest aktem konstytuującym przestrzeń międzypodmiotowej relacji i jest rezygnacją z pozycyjności zdystansowanego obserwatora, który udostępnia się poprzez swą obecność, bycie bliskim, dostępnym, w akcie znoszenia swego „urzędowego ufortyfikowania”. 


\section{The philosophy of the dialogue and its pedagogical implications (Summary)}

The way in which the human being is perceived is central to the philosophy of the dialogue. It presents the man as the one focused on himself, but all the same as someone who is prepared to begin a relationship with others. Different philosophers of the dialogue perceived these issues in various ways. It should also be added that the philosophy of the dialogue is rooted in the opposition to the general tendencies of modern philosophy, as it negates both the object and subject. It is also the philosophy of deeds: it separates the man from the world of pure ideas on the behalf of the experiences based on the existential and face-to-face relationships between people. The other man is perceived here as the most fundamental reality of existential experience. Therefore, the upbringing process involves freeing and activating personal possibilities of the Other man, authentic "being for someone", encouraging pupils/students by the means of personal model, as well as being sensitive to others. 